PART I. DISEASES AND PROBLEMS DISTINGUISHED BY WHO AND FAO DZIAŁ I. CHOROBY I PROBLEMY WYRÓŻNIONE PRZEZ WHO I FAO

\title{
ASSOCIATION BETWEEN BODY MASS INDEX AND GASTRIC CANCER IN POMERANIAN MEN AND WOMEN
}

\section{ZWIĄZEK POMIĘDZY WSKAŹNIKIEM MASY CIAŁA I WYSTĘPOWANIEM GRUCZOŁOWEGO RAKA ŻOŁĄDKA WŚRÓD MĘŻCZYZN I KOBIET W WOJEWÓDZTWIE POMORSKIM}

\author{
Krzysztof Adamowicz ${ }^{1,2(A, B, C, D, E, F)}$ \\ ${ }^{1}$ F. Ceynowa Specialist Hospital in Wejherowo, Poland \\ ${ }^{2}$ Provincial Center of Oncology in Gdansk COPERNICUS, Poland
}

Authors' contribution Wkład autorów: A. Study design/planning zaplanowanie badań B. Data collection/entry zebranie danych C. Data analysis/statistics dane - analiza i statystyki D. Data interpretation interpretacja danych E. Preparation of manuscript przygotowanie artykułu F. Literature analysis/search wyszukiwanie i analiza literatury G. Funds collection zebranie funduszy

\section{Tables: 2}

Figures: 1

References: 36

Submitted: 2017 Jan 25

Accepted: 2017 Feb 28

\section{Summary}

Background. Within the last few decades, the prevalence of obesity has increased rapidly throughout the world. Epidemiological studies indicate a relationship of several types of cancer with obesity. The study aimed was to analyse the relation between body mass index (BMI) and the risk of developing gastric cancer.

Material and methods. A multicenter case-control study was conducted between 2010 and 2015 in Poland. The study included 152 patients with gastric cancer and 152 patients with normal results of esophagogastroduodenoscopy performed in the same period and matched for age, education and sex. BMI was calculated by using patients' height and weight. An analysis of environmental factors associated with the risk of gastric cancer was performed.

Results. The group with the diagnosis of gastric cancer was characterised by significantly higher regular consumption of alcohol and was found to include a higher percentage of smokers compared to the control group. In a subgroup analysis, it was found that there was a significantly higher body mass index among both men and women diagnosed with gastric cancer. A relation between gastric cancer and both overweight (BMI $25.0-29.9 \mathrm{~kg} / \mathrm{m}^{2}$ ) and obesity $\left(\mathrm{BMI} \geq 30 \mathrm{~kg} / \mathrm{m}^{2}\right.$ ) was established. In a multivariate analysis, this was an independent risk factor for gastric cancer.

Conclusions. We suggest that BMI should be considered as an independent risk factor for developing gastric adenocarcinoma, which should lead to further research leading to the development of recommendations for the prevention of gastric cancer for people with high BMI.

Keywords: gastric cancer, body mass index, public health, overweight

\section{Streszczenie}

Wprowadzenie. W ciągu ostatnich kilku dekad występowanie nadwagi i otyłości wzrasta gwałtownie. Badania epidemiologiczne wskazują na związek kilku typów nowotworów złośliwych z nadwagą i otyłością. Celem naszej pracy była analiza relacji pomiędzy wskaźnikiem masy ciała (BMI) a ryzykiem zachorowania na gruczołowego raka żołądka.

Materiał i metody. Wieloośrodkowe badanie kliniczno-kontrolne zostało przeprowadzone w latach 2010 do 2015 w województwie pomorskim w Polsce. Do badania włączono 152 pacjentów z rakiem żołądka i 152 pacjentów z prawidłowymi wynikami ezofagoduodendoskopii wykonywanymi w tym samym okresie. Przypadki zostały dopasowane pod względem wieku, wykształcenia i płci. BMI obliczano na podstawie wzrostu i wagi pacjenta. Dodatkowo przeprowadzono analizę czynników środowiskowych mogących mieć związek z ryzykiem zachorowania na gruczołowego raka żołądka.

Wyniki. W grupie z rozpoznaniem raka żołądka stwierdzano wyraźnie wyższą częstość regularnego spożywania alkoholu i wyższy odsetek osób palących w porównaniu do grupy kontrolnej. W analizie podgrup stwierdzono znacznie podwyższony wskaźnik masy ciała zarówno wśród mężczyzn jak i kobiet, u których zdiagnozowano raka żołądka w stosunku do grupy kontrolnej. Relacja pomiędzy występowaniem raka żołądka i nadwagi (BMI 25.0-29.9 kg $/ \mathrm{m}^{2}$ ) lub otyłości (BMI $\geq 30 \mathrm{~kg} / \mathrm{m}^{2}$ ) była istotna statystycznie. W analizie wieloczynnikowej podwyższony BMI był niezależnym czynnikiem ryzyka rozwoju gruczołowego raka żołądka.

Wnioski. Sugerujemy, że BMI należy traktować jako niezależny czynnik ryzyka rozwoju gruczolakoraka żołądka, co powinno prowadzić do dalszych badań prowadzących do opracowania zaleceń dotyczących zapobieganiu i wczesnemu wykrywaniu raka żołądka u osób z wysokim BMI.

Słowa kluczowe: rak żołądka, wskaźnik masy ciała, zdrowie publiczne, nadwaga

Adamowicz K. Association between Body Mass Index and gastric cancer in Pomeranian men and women. Health Prob Civil. 2018; 12 (4): 231 -237. https://doi.org/10.5114/hpc.2018.76517

Address for correspondence / Adres korespondencyjny: Krzysztof Adamowicz, Provincial Center of Oncology in Gdansk COPERNICUS, Zwycięstwa 32, 80-210 Gdansk, Poland, e-mail: krzys.adamowicz@gmail.com, phone: +48585727794

Copyright: (C) Pope John Paul II State School of Higher Education in Biała Podlaska, Krzysztof Adamowicz. This is an Open Access journal, all articles are distributed under the terms of the Creative Commons Attribution-NonCommercial-ShareAlike 4.0 International (CC BY-NC-SA 4.0) License (http://creativecommons.org/licenses/by-nc-sa/4.0/), allowing third parties to copy and redistribute the material in any medium or format and to remix, transform, and build upon the material, provided the original work is properly cited and states its license. 


\section{Introdution}

Over the past decades, there has been observed a continuous increase in the incidence of adenocarcinoma of the distal oesophagus, gastroesophageal junction and of the stomach (later in this paper, to simplify it, we will use the name: gastric adenocarcinoma) [1]. Despite the decreasing incidence of gastric cancer in recent decades all over the world, it remains the fourth most common cancer and the third leading cause of cancerrelated deaths in men and the fifth leading cause of cancer-related deaths in women [2]. There is evidence that specific environmental factors increase the risk of gastric cancer, e.g. smoking, excessive alcohol intake, low intake of fruit and vegetables and high intake of smoked food [3-5]. Moreover, a relationship between the risk of gastric cancer and chronic Helicobacter pylori infection has been found [6]. Most of these data come from Asian countries. This is, however, consistent with the data presented in the report of the World Cancer Research Fund and the American Institute for Cancer Research (WCRF / AICR) in 2007, where the major causes of cancers are environmental factors and factors related to lifestyle, such as diet, insufficient physical activity, excessive alcohol consumption and smoking [7].

The prevalence of overweight and obesity has been increasing worldwide in recent decades. It is well known that obesity leads to many adverse health effects, including increased risk of cancer. Many studies support the hypothesis that elevated BMI is associated with an increased risk of certain cancers, e.g. there is a welldemonstrated association between obesity and an increased risk of developing colorectal cancer, pancreatic cancer, and kidney cancer [8-13]. On the other hand, there are reports in the literature of a reduced risk of developing lung cancer with increasing BMI [14-15]. In addition, no correlation has been established between BMI and the risk of prostate cancer [16-17], or rectal cancer [18-19]. Given the various effects BMI has on the incidence of various cancers, the question of obesity's influence on the long-term incidence of cancers is still open to debate.

In the case of gastric cancer, several studies have shown a correlation between body mass index (BMI) and an increased risk of gastric cancer, which was confirmed in the meta-analysis [20]. In some studies, however, this correlation remained inconclusive, dependent on sex, the type of obesity, or Helicobacter pylori infection [21-24]. The purpose of the study presented here was to investigate the relationship between BMI and the risk of gastric cancer in the Polish society (taking into consideration the family history and the infection of Helicobacter pylori in gastric cancer, against eating habits, alcohol consumption and smoking).

\section{Material and methods}

The study included a total of three hundred and four people who had esophagogastroduodenoscopy in the F. Ceynowa Specialist Hospital in Wejherowo and in the Regional Oncology Centre in Gdansk, Poland, from May 2010 to December 2015. During this period a total of 153 cases of gastric adenocarcinoma were diagnosed by histopathology. One person was excluded from the study due to incomplete survey data. The control group was selected and matched from healthy patients who had esophagogastroduodenoscopy at the same time. Each case was matched individually with a control according to certain characteristics such as age, education, and gender. All study participants had their case history taken by a gastroenterologist, a surgeon, or a clinical oncologist, including their medical history, family history of cancers, obstetric/gynecological history in women and the factors related to lifestyle, including smoking and alcohol consumption. In each patient, a test for the presence of Helicobacter pylori infection was performed. Anthropometric information (height and weight) were measured by a qualified treatment nurse. Body weight and height were measured according to standard protocols with an accuracy corresponding to $0.1 \mathrm{~kg}$ and $1.0 \mathrm{~cm}$. The study was based on a retrospective analysis of documents and the clinical treatment history of patients. Before the analysis, a database was prepared, consisting of the following columns: age, sex, education, smoking, alcohol consumption, significant burdens and chronic diseases, family history of diseases, gynecological history, Helicobacter pylori infection, height, weight, BMI, the final diagnosis. A current smoker was defined as a person who had smoked an average of at least one cigarette per day during the preceding 12 months. A former smoker was defined as someone who did not meet this definition but had smoked before. People who had never smoked were considered non-smokers. Drinking alcohol was defined as consuming at least three alcoholic drinks of any kind per week. These data were obtained basing on patients' own reporting in a standard patient questionnaire. A positive family history of gastric cancer was defined as an occurrence of this disease in first and /or second-degree relatives. The presence of chronic diseases was defined as answering "yes" to the question: "Have you ever been diagnosed with the following chronic diseases?". All patients were weighed and measured by a treatment nurse. BMI was defined as the ratio of the body weight (expressed in kg) divided by the square of the body height (in meters) (weight [kg] / height [m2]). BMI ranges were adopted in accordance with the definitions from WHO criteria. BMI values were divided into four groups: 
underweight (BMI of less than $18.5 \mathrm{~kg} / \mathrm{m} 2$ ), normal BMI (from 18.5 to $24.99 \mathrm{~kg} / \mathrm{m} 2$ ), overweight (from 25 to $29.99 \mathrm{~kg} / \mathrm{m} 2$ ) and obesity ( $\geq 30.0 \mathrm{~kg} / \mathrm{m} 2$ ) (Table 1).

Table 1. BMI by WHO

\begin{tabular}{|c|c|}
\hline body mass index & classification \\
\hline $0-18.49$ & underweight \\
\hline $18.5-24.9$ & normal \\
\hline $25-29.9$ & overweight \\
\hline $30-34.9$ & obese \\
\hline $35-40$ and above & morbidly obese \\
\hline
\end{tabular}

The project was approved by the Bioethics Commission at the Regional Medical Council in Gdansk and by the directors of both hospitals. The condition of consent was the preparation of a database with complete anonymity of the study group.

\section{Statistical methods}

To calculate the BMI, measurements of height and weight carried at the day of esophagogastroduodenoscopy (the body weight in kilograms divided by the square of the body height in meters) were used. Differences in epidemiological factors between the groups of patients with gastric adenocarcinoma and the control group were tested using the Student's t-test for continuous variables and the Chi-square test for categorical variables. All tests were two-tailed and a p-value less than 0.05 was considered statistically significant. For statistical calculations, programs: Microsoft Excel version 2003 and PQStat version 1.4. were used.

To examine the relationship between BMI and the risk of gastric cancer, non-parametric logistic regression was used. For this purpose, following variables were used: age (continuous), smoking, alcohol consumption, family history of gastric cancer, chronic diseases (separately for patients with diabetes, chronic gastritis, and stomach ulcers), and Helicobacter pylori infection. In addition, for women, menopause was included in the logistic regression analysis.

\section{Results}

During the study (on average 66 months for both centres) 153 cases of gastric adenocarcinoma were found. Selected epidemiological data and the characteristics of the respondents are summarised in Table 2.

Table 2. Selected characteristics of 152 gastric cancer cases and 152 controls

\begin{tabular}{|c|c|c|c|c|c|c|c|c|c|c|}
\hline \multirow{3}{*}{ variable } & \multicolumn{5}{|c|}{ men } & \multicolumn{5}{|c|}{ women } \\
\hline & \multicolumn{2}{|c|}{ case $(n=109)$} & \multicolumn{2}{|c|}{$\begin{array}{c}\text { control } \\
(\mathrm{n}=109)\end{array}$} & \multirow{2}{*}{$\mathbf{p}$} & \multicolumn{2}{|c|}{ case $(n=43)$} & \multicolumn{2}{|c|}{ control $(n=43)$} & \multirow{2}{*}{$\mathbf{p}$} \\
\hline & $\mathbf{n}$ & $\%$ & $\mathbf{n}$ & $\%$ & & $\mathbf{n}$ & $\%$ & $\mathbf{n}$ & $\%$ & \\
\hline age (years, mean \pm SD) & \multicolumn{2}{|c|}{$63.6 \pm 9.3$} & \multicolumn{2}{|c|}{$63.3 \pm 9.8$} & 0.47 & \multicolumn{2}{|c|}{$64.3 \pm 8.7$} & \multicolumn{2}{|c|}{$64.0 \pm 9.3$} & 0.71 \\
\hline smoking & 83 & 76.1 & 64 & 58.7 & $<0.01$ & 25 & 58.1 & 11 & 25.5 & $<0.01$ \\
\hline drinkingalcohol & 68 & 62.3 & 42 & 38.5 & $<0.01$ & 12 & 27.9 & 7 & 16.2 & $<0.01$ \\
\hline $\begin{array}{l}\text { family history of gastric } \\
\text { cancer }\end{array}$ & 29 & 26.6 & 6 & 5.5 & $<0.01$ & 9 & 20.9 & 1 & 2.3 & $<0.01$ \\
\hline \multicolumn{11}{|c|}{ medical history } \\
\hline diabetes mellitus & 12 & 11.0 & 13 & 11.9 & 0.16 & 6 & 13.9 & 5 & 11.6 & 0.35 \\
\hline chronic gastritis & 23 & 21.1 & 15 & 13.7 & $<0.01$ & 7 & 16.2 & 8 & 18.6 & 0.41 \\
\hline $\begin{array}{l}\text { helicobacter pylori infec- } \\
\text { tion }\end{array}$ & 72 & 66.1 & 70 & 54.2 & 0.18 & 36 & 83.7 & 35 & 81.4 & 0.49 \\
\hline menopause & & & & & & 41 & 95.3 & 39 & 90.7 & 0.37 \\
\hline \multicolumn{11}{|c|}{ BMI Information (mean \pm SD) } \\
\hline BMI & \multicolumn{2}{|c|}{$27.3 \pm 1.18$} & \multicolumn{2}{|c|}{$24.8 \pm 1.22$} & $<0.01$ & \multicolumn{2}{|c|}{$29,4 \pm 1.73$} & \multicolumn{2}{|c|}{$26.3 \pm 1.1$} & $<0.01$ \\
\hline height $(\mathrm{cm})$ & \multicolumn{2}{|c|}{$173.5 \pm 9.8$} & \multicolumn{2}{|c|}{$173.2 \pm 9.4$} & 0.24 & \multicolumn{2}{|c|}{$165.8 \pm 7.9$} & \multicolumn{2}{|c|}{$165.5 \pm 8.4$} & 0.29 \\
\hline weight (kg) & \multicolumn{2}{|c|}{$83.1 \pm 11.4$} & \multicolumn{2}{|c|}{$75.5 \pm 10.8$} & $<0.01$ & \multicolumn{2}{|c|}{$81.2 \pm 10.8$} & \multicolumn{2}{|c|}{$72.6 \pm 7.7$} & $<0.01$ \\
\hline
\end{tabular}

$\mathrm{p}$ value calculated by Chi-square test for categorical variables and t test for continuous variables 
The mean age of the patients was 63.6 for men and 64.3 for women. The group of patients with gastric cancer was more likely to have a positive family history of gastric cancer than the control group (26.6\% vs 5.5\% for men and $20.9 \%$ vs. $2.3 \%$ for women respectively). In addition, the group with cancer included more smokers, both among men (76.1\% vs $58.7 \%$ ) and among women (58.1\% vs $25.5 \%)$. Alcohol consumption was also more frequent in patients with gastric cancer, both in men (62.3\% vs. $38.5 \%)$ and women (27.9\% vs $16.2 \%)$. Moreover, in the case of men, there was a difference established in the incidence of chronic gastritis and peptic ulcers (21.1\% vs $13.7 \%)$. In women, there was no difference of this kind (16.2\% vs $18.6 \%)$. There was no statistically significant difference between groups, when it comes to the percentage of post-menopausal women (95.3\% vs 90.7\%). No effect of Helicobacter pylori infection on the increased risk of gastric adenocarcinoma was found.

Body weight was significantly higher in patients diagnosed with gastric cancer compared to the control group, both among men $(88.1 \pm 11.4 \mathrm{~kg}$ and $80.5 \pm 10.8 \mathrm{~kg}$ respectively) and women $(86.2 \pm 10,8$ compared to $77.6 \pm 7.7 \mathrm{~kg})$.

The relation between BMI and the risk of gastric cancer is shown graphically in Fig. 1.

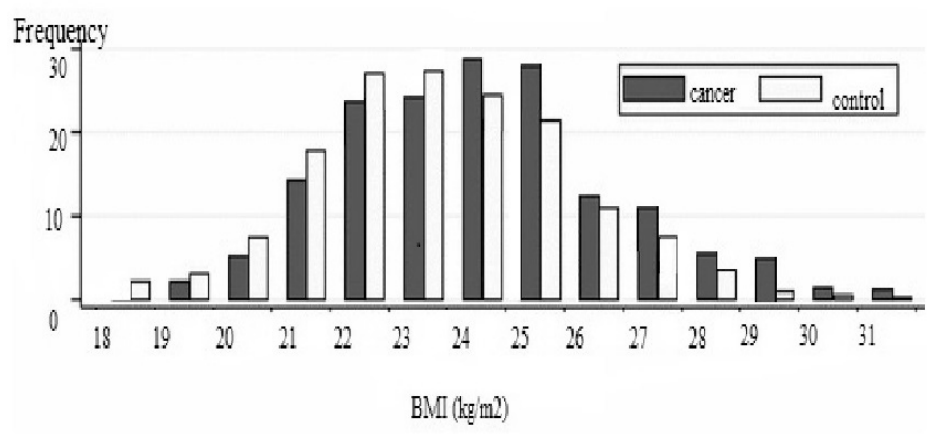

Figure 1. The association between BMI and gastric cancer risk

Taking BMI of $21.75 \mathrm{~kg} / \mathrm{m} 2$ as an optimum, the risk of gastric cancer increases in men with BMI higher than or equal to $25.0 \mathrm{~kg} / \mathrm{m} 2$, whereas in women, the risk increases in patients with BMI of $25.3 \mathrm{~kg} / \mathrm{m} 2$ or more. The odds ratio is estimated at more than two in men with BMI over $28.7 \mathrm{~kg} / \mathrm{m} 2$ and in women with BMI over $28.5 \mathrm{~kg} / \mathrm{m} 2$.

\section{Discussion}

Over the past several decades we have seen a significant increase in the incidence of adenocarcinoma of the gastroesophageal junction in the populations of Western countries, in contrast to a decrease in the incidence of cancer of the distal stomach [25]. In the literature, there is a hypothesis that this trend is a result of an increasing rate of Helicobacter pylori eradication. This hypothesis may indicate that adenocarcinomas are not associated with Helicobacter pylori infection but with other environmental factors, such as diet, smoking, alcohol consumption and obesity. In our study, we analysed the relationship between BMI, smoking, alcohol consumption, and increased risk of gastric cancer, assuming that BMI is associated with an increased risk of gastric cancer. Our results indicate that the BMI is a substantial risk factor for developing gastric cancer. After excluding the impact of other known epidemiological risk factors for developing gastric cancer, high BMI has remained significantly related to the risk of gastric cancer (both in men and women).

There are at least a few mechanisms that may explain the relation between overweight and obesity and an increased risk of developing this type of cancer. First, the accumulation of body fat increases the concentration of endogenous hormones, such as insulin and the insulin-like growth factor-1, as well as steroids. The result of these hormones' influence is an increase in cell proliferation and the weakening of apoptosis, which, consequently, spurs the growth of malignant cells. Also, insulin resistance and chronic hyperinsulinemia, produced by the metabolic adaptation to increased levels of free fatty acids circulation from adipose tissue can be conducive to developing cancer [26]. Secondly, overweight and obesity can promote the formation of Barrett's oesophagus, which is a precancerous condition [27]. One possible mechanism is an increase of intra-abdominal pressure on the lower oesophageal sphincter $[26,28]$. Thirdly, the level of estrogen, which is closely associated with obesity, may be associated with an increased risk of certain cancers [29]. Fourth, obesity increases the release of inflammatory mediators that can promote tumour growth [30]. It is also suggested that obese people have prolonged passage through the oesophagus, resulting in a longer contact time between the oesophageal mucosa and food (containing potentially carcinogenic ingredients) [31]. 
However, even these suggested mechanisms explaining the link between obesity and the development of cancer are not sufficient. Reflecting on other causes, one must mention population ageing. People live longer, and the incidence of cancer has been significantly associated with ageing [32]. In the present study, the risk of gastric cancer was related to age and was significantly higher in patients older than 60, in comparison with those under the age of 60.

Another well-known risk factor for cancer is tobacco smoke, containing many chemical carcinogens, which can operate through direct contact with gastric mucosa or indirectly by the flow of blood. The cause-effect relationship between smoking and gastric cancer has been the subject of controversy in the past 20 years. A meta-analysis published in 1997 showed, however, that such a relation exists [33]. Our study also shows an increased risk of gastric cancer among current smokers. This correlation has been observed in both men and women.

The risk of gastric cancer is increased in patients with a positive family history of this cancer [34]. The risk of gastric cancer increases from 1.5 to 3.5 times in the case of family history of the disease. Of course, this may be since relatives tend to be exposed to the same environmental risk factors, but the influence of genetic factors cannot be excluded. Our study confirms that the presence of gastric cancer in first- and second-degree relatives increases the risk of developing this type of cancer. In addition, the risk was independent of smoking tobacco, BMI, education, sex, and age in the multivariate analysis.

This study has, however, several potential limitations, which should be considered in the analysis. Firstly, our study has a potential bias. Patients were recruited from hospitals performing treatments for gastric cancer. Secondly, the control group was not completely healthy. These were patients who volunteered to perform esophagogastroduodenoscopy, due to gastroenterological symptoms. To overcome this problem, we have compared the cases of disease with a control group, which had the same demographic profile and comorbidities. In fact, there is no significant difference between the groups regarding education, age, and sex. These variables were equalised in the selection of the control group.

Recently, a meta-analysis based on prospective studies has demonstrated that BMI is a risk factor for developing gastric cancer [35]. However, half of the studies which were included were based on self-reports of anthropometric data, which could lead to an overestimation of the relative risk [36]. The advantage of our study is that the data on weight and height were collected by a qualified nurse. As for the history of smoking and alcohol consumption, the situation was different, and the amount of alcohol consumed was very imprecise. Besides, our study did not include other factors, such as diet, physical activity or the amount of non-steroidal anti-inflammatory drugs taken.

\section{Conclusions}

Although the study involved a small population, it revealed a positive relation between BMI and gastric cancer. In summary, this study provides additional information to previous studies on the effect of BMI on the risk of gastric cancer. The results of our study may shed light on public health, stressing the importance of weight control in the prevention of gastric cancer. We suggest that BMI should be considered as an independent risk factor for developing gastric adenocarcinoma, which should lead to further research leading to the development of recommendations for the prevention of gastric cancer for people with high BMI.

\section{References:}

1. Thrift AP, Whiteman DC. The incidence of oesophageal adenocarcinoma continues to rise: analysis of period and birth cohort effects on recent trends. Ann Oncol. 2012; 23(12): 3155-62. https://doi.org/10.1093/annonc/mds181

2. Siegel R, Naishadham D, Jemal A. Cancer statistics. CA Cancer J Clin. 2013; 63(1): 11-30. https://doi.org/10.3322/caac.21166

3. Ladeiras-Lopes R, Pereira AK, Nogueira A, Pinheiro-Torres T, Pinto I, Santos-Pereira R, et al. Smoking and gastric cancer: systematic review and meta-analysis of cohort studies. Cancer Causes Control. 2008; 19(7): 689-701. https://doi.org/10.1007/s10552-008-9132-y

4. Sung NY, Choi KS, Park EC, Park K, Lee SY, Lee AK, et al. Smoking, alcohol and gastric cancer risk in Korean men: the National Health Insurance Corporation Study. Br J Cancer. 2007; 97(5): 700-4. https://doi.org/10.1038/sj.bjc.6603893

5. Shikata K, Kiyohara Y, Kubo M, Yonemoto K, Ninomiya T, Shirota T, et al. A prospective study of dietary salt intake and gastric cancer incidence in a defined Japanese population: the Hisayama study. Int J Cancer. 2006; 119(1): 196-201. https://doi.org/10.1002/ijc.21822 
6. Uemura N, Okamoto S, Yamamoto S, Matsumura N, Yamaguchi S, Yamakido M, et al. Helicobacter pylori infection and the development of gastric cancer. N Engl J Med. 2001; 345(11): 784-9. https://doi.org/10.1056/NEJMoa001999

7. World Cancer Research Fund and American Institute for Cancer Research. Food, nutrition, physical activity, and the prevention of cancer: a global perspective. Washington, DC: AICR; 2007.

8. Rapp K, Schroeder J, Klenk J, Stoehr S, Ulmer H, Concin H, et al. Obesity and incidence of cancer: a large cohort study of over 145,000 adults in Austria. Br J Cancer. 2005; 93(9): 1062-7. https://doi.org/10.1038/sj.bjc.6602819

9. Ford ES. Body mass index and colon cancer in a national sample of adult US men and women. Am J Epidemiol. 1999; 150(4): 390-8. https://doi.org/10.1093/oxfordjournals.aje.a010018

10. Samanic C, Chow WH, Gridley G, Jarvholm B, Fraumeni JF Jr. Relation of body mass index to cancer risk in 362,552 Swedish men. Cancer Causes Control. 2006; 17(7): 901-9. https://doi.org/10.1007/s10552-006-0023-9

11. Bassett JK, Severi G, English DR, Baglietto L, Krishnan K, Hopper JL, et al. Body size, weight change, and risk of colon cancer. Cancer Epidemiol Biomarkers Prev. 2010; 19(11): 2978-86. https://doi.org/10.1158/1055-9965.EPI-10-0543

12. Reeves GK, Pirie K, Beral V, Green J, Spencer E, Bull D. Cancer incidence and mortality in relation to body mass index in the Million Women Study: cohort study. BMJ. 2007; 335(7630): 1134-44. https://doi.org/10.1136/bmj.39367.495995.AE

13. Adams KF, Leitzmann MF, Albanes D, Kipnis V, Moore SC, Schatzkin A, et al. Body size and renal cell cancer incidence in a large US cohort study. Am J Epidemiol. 2008; 168(3): 268-77. https://doi.org/10.1093/aje/kwn122

14. Kabat GC, Miller AB, Rohan TE. Body mass index and lung cancer risk in women. Epidemiology. 2007; 18(5): 607-12. https://doi.org/10.1097/EDE.0b013e31812713d1

15. Kabat GC, Kim M, Hunt JR, Chlebowski RT, Rohan TE. Body mass index and waist circumference in relation to lung cancer risk in the Women's Health Initiative. Am J Epidemiol. 2008; 168(2): 158-69. https://doi.org/10.1093/aje/kwn109

16. Wright ME, Chang SC, Schatzkin A, Albanes D, Kipnis V, Mouw T, et al. Prospective study of adiposity and weight change in relation to prostate cancer incidence and mortality. Cancer. 2007; 109(4): 675-84. https://doi.org/10.1002/cncr.22443

17. Pischon T, Boeing H, Weikert S, Allen N, Key T, Johnsen NF, et al. Body size and risk of prostate cancer in the European prospective investigation into cancer and nutrition. Cancer Epidemiol Biomarkers Prev. 2008; 17(11): 3252-61. https://doi.org/10.1158/1055-9965.EPI-08-0609

18. Pischon T, Lahmann PH, Boeing H, Friedenreich C, Norat T, Tjønneland A, et al. Body size and risk of colon and rectal cancer in the European Prospective Investigation Into Cancer and Nutrition (EPIC). J Natl Cancer Inst. 2006; 98(13): 920-31. https://doi.org/10.1093/jnci/djj246

19. Adams KF, Leitzmann MF, Albanes D, Kipnis V, Mouw T, Hollenbeck A, et al. Body mass and colorectal cancer risk in the NIH-AARP cohort. Am J Epidemiol. 2007; 166(1): 36-45. https://doi.org/10.1093/aje/kwm049

20. Lin XJ, Wang CP, Liu XD, Yan KK, Li S, Bao HH, et al. Body mass index and risk of gastric cancer: a metaanalysis. Jpn J Clin Oncol. 2014; 44(9): 783-91. https://doi.org/10.1093/jjco/hyu082

21. Kim HJ, Kim N, Kim HY, Lee HS, Yoon H, Shin CM, et al. Relationship between body mass index and the risk of early gastric cancer and dysplasia regardless of Helicobacter pylori infection. Gastric Cancer. 2015; 18(4): 762-73. https://doi.org/10.1007/s10120-014-0429-0

22. Merry AH, Schouten LJ, Goldbohm RA, van den Brandt PA. Body mass index, height and risk of adenocarcinoma of the oesophagus and gastric cardia: a prospective cohort study. Gut. 2007; 56(11): 1503-11. https://doi.org/10.1136/gut.2006.116665

23. Buckland G, Travier N, Huerta JM, Bueno-de-Mesquita HB, Siersema PD, Skeie G, et al. Healthy lifestyle index and risk of gastric adenocarcinoma in the EPIC cohort study. Int J Cancer. 2015; 137(3): 598-606. https://doi.org/10.1002/ijc.29411

24. Steffen A, Huerta JM, Weiderpass E, Bueno-de-Mesquita HB, May AM, Siersema PD, et al. General and abdominal obesity and risk of esophageal and gastric adenocarcinoma in the European Prospective Investigation into Cancer and Nutrition. Int J Cancer. 2015; 137(3): 646-57. https://doi.org/10.1002/ijc.29432

25. Brown LM, Devesa SS. Epidemiologic trends in esophageal and gastric cancer in the United States. Surg Oncol Clin N Am. 2002; 11(2): 235-56. https://doi.org/10.1016/S1055-3207(02)00002-9

26. La Vecchia C, Negri E, Lagiou P, Trichopoulos D. Oesophageal adenocarcinoma: a paradigm of mechanical carcinogenesis? Int J Cancer. 2002; 102: 269-70. https://doi.org/10.1002/ijc.10697 
27. Wu AH, Tseng CC, Bernstein L. Hiatal hernia, reflux symptoms, body size, and risk of esophageal and gastric adenocarcinoma. Cancer. 2003; 98(5): 940-8. https://doi.org/10.1002/cncr.11568

28. Barak N, Ehrenpreis ED, Harrison JR, Sitrin MD. Gastro-oesophageal reflux disease in obesity: pathophysiological and therapeutic considerations. Obes Rev. 2002; 3(1): 9-15. https://doi.org/10.1046/j.1467-789X.2002.00049.x

29. Calle EE, Kaaks R. Overweight, obesity and cancer: epidemiological evidence and proposed mechanisms. Nat Rev Cancer. 2004; 4(8): 579-91. https://doi.org/10.1038/nrc1408

30. Balkwill F, Mantovani A. Inflammation and cancer: back to Virchow? Lancet. 2001; 357(9255): $539-45$. https://doi.org/10.1016/S0140-6736(00)04046-0

31. Mercer CD, Rue C, Hanelin L, Hill LD. Effect of obesity on esophageal transit. Am J Surg. 1985; $149(1): 177-81$. https://doi.org/10.1016/S0002-9610(85)80029-5

32. Anisimov VN, Sikora E, Pawelec G. Relationships between cancer and aging: a multilevel approach. Biogerontology. 2009; 10(4): 323-38. https://doi.org/10.1007/s10522-008-9209-8

33. Trédaniel J, Boffetta P, Buiatti E, Saracci R, Hirsch A. Tobacco smoking and gastric cancer: review and metaanalysis. Int J Cancer. 1997; 72(4): 565-73. https://doi.org/10.1002/(SICI)1097-0215(19970807)72:4<565::AID-IJC3>3.0.CO;2-O

34. Dhillon PK, Farrow DC, Vaughan TL, Chow WH, Risch HA, Gammon MD, et al. Family history of cancer and risk of esophageal and gastric cancers in the United States. Int J Cancer. 2001; 93(1): 148-52. https://doi.org/10.1002/ijc.1294

35. Chen Y, Liu L, Wang X, Wang J, Yan Z, Cheng J, et al. Body mass index and risk of gastric cancer: a meta-analysis of a population with more than ten million from 24 prospective studies. Cancer Epidemiol Biomarkers Prev. 2013; 22(8): 1395-408. https://doi.org/10.1158/1055-9965.EPI-13-0042

36. Park JY, Mitrou PN, Keogh RH, Luben RN, Wareham NJ, Khaw KT, et al. Self-reported and measured anthropometric data and risk of colorectal cancer in the EPIC-Norfolk study. Int J Obes. 2012; 36(1): 107-18. https://doi.org/10.1038/ijo.2011.61 